Joanna Panasiuk

\title{
Ancient Polish Books in the Buryatian Republic near Mongolia
}

$\mathrm{T}$ he Republic of Buryatia is a part of the Russian Federation sharing its southern border with Mongolia. The local church of Old Believers of the Orthodox rite in the remote village of Tarbagatai keeps some old liturgical books. Eight of them were printed in the eighteenth century in the cities of Supraśl, Grodno and Vilnius, at that time located in eastern Poland.

The Orthodox Old Believers, also called "Old Ritualists", are a faction of the Russian Orthodox Church. At the end of the seventeenth century they flooded into the eastern part of Poland, fleeing from Russia where their refusal to accept the liturgical reforms imposed by the Orthodox Patriarch Nikon of Moscow was putting them in danger (CubrzyńskaLeonarczyk 2007 ; Przybył 1999). In our country, they were free to practice their religious rites, and were allowed to order printings of the books they needed for worship at the local printers belonging to the Greek Catholic Church of the Russian rite (Iwaniec 1977: 37-138, 281-282 ; CubrzyńskaLeonarczyk: 28-41).

All the books found at Tarbagatai are in good or very good condition. The passage of time is only visible on the first and last pages, damaged or torn in some manuscripts. Some of the books have evidently not been used at all: the pages are uncut and there is no noticeable folding, suggesting

This is an Open Access article distributed under the terms of the Creative Commons Attribution 3.0 PL License (creativecommons.org/licenses/by/3.0/pl/), which permits redistribution, commercial and non-commercial, provided that the article is properly cited. (C) The Author(s), 2014

Publisher: Institute of Slavic Studies, Polish Academy of Sciences

Editor in chief: Jolanta Sujecka

Conception and academic editing of this issue: Maciej Falski 


\section{| Joanna Panasiuk}

that these books have been used. All the books have thick protective leather covers with engraved ornaments. Each book has clips on both sides used to fix the fasteners, or marks of such clips. The books vary in size from 10 to $34 \mathrm{~cm}$, with 300 to 1500 pages. The margins of the biggest books are very wide, measuring up to $5 \mathrm{~cm}$. The texts of the books discovered in Tarbagatai belong to the traditional liturgical literature, including liturgical prayers, the prayers for each day of the liturgical calendar, and explications of the Scriptures.

One of the larger works, having 820 pages and dated 1790 (Cf. picture 1: last page of the book), was printed in Supraśl in the Podlasie region in the east of Poland. This book, intended for priests or other members of literacy elites, contains commentary on the Gospel prepared for every Sunday and Holy day of the liturgical year.

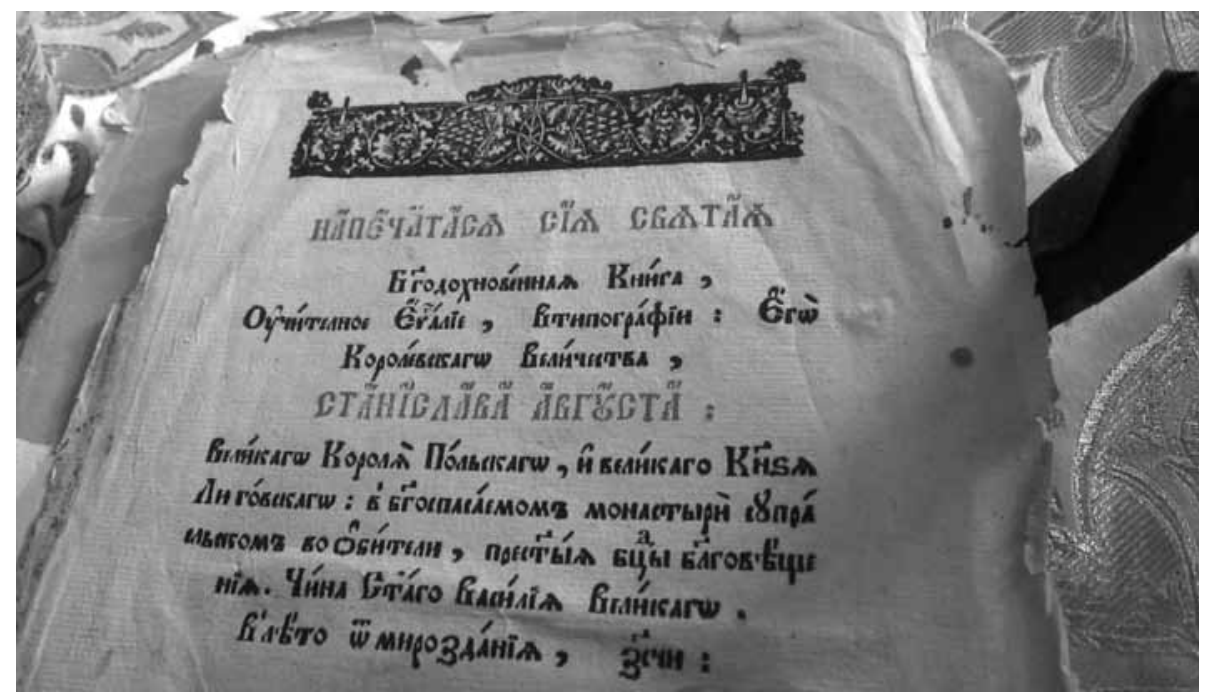

Picture 1

Another example of a theme used in the literature of old-Orthodox worship is the suffering of Christ. It is in the Jewish tradition (Prejs 1989: 50-234; Korolko 1978; Rzepka, Wydra 1996; Górski 1965: XLI-XLII; Nieznanowski 1989: 22-23; Michałowska 1996: 457) that the cult has its source. One of the books found in Tarbagatai that deserves our attention deals with the Passion of Christ (cf. picture 2 - table of content). It's one of the small manuscripts and was printed in 1794 in Supraśl, like the previous book.

The text of this book was entirely based on the Apocryphal of the New Testament that develops in details the stories contained in the Bible. The four Gospels provide little information about the Passion of Jesus. The 


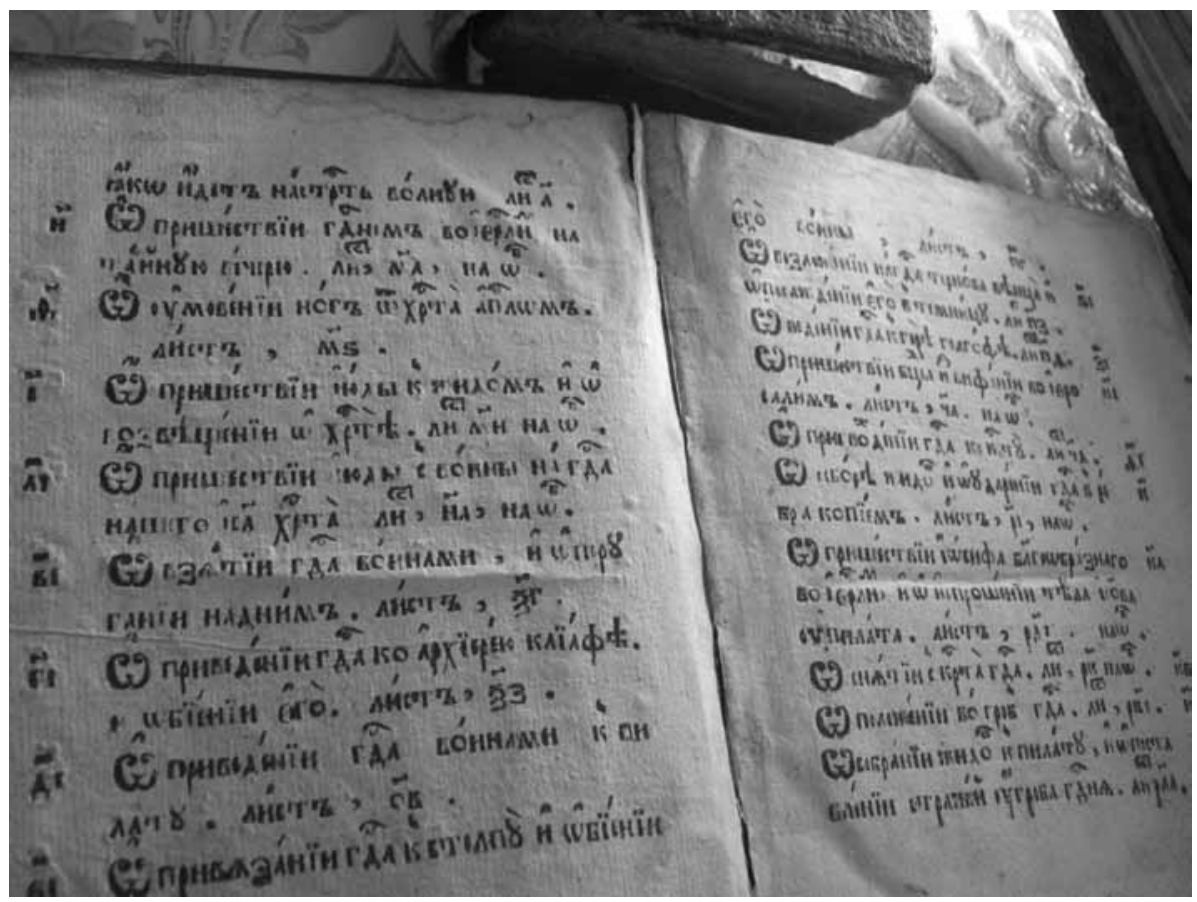

Picture 2

author of the text of this ancient book uses the apocryphal writings to create detailed images of the Lord and of his suffering. The starting point of this paper is the Last Supper, then a visit to Pilate, followed by the road to Golgotha. This description should be used to arouse emotion in the reader: awaken their compassion, regret, encourage their tears. The content is thus made up of images of extra-biblical details enriched with naturalistic scenes of the Lord's suffering. Let us remember that influencing the reader to capture his psyche was one of the rules of the art of ancient times (Prejs 1989: 133-226).

In all the books found in the church of Tarbagatai, titles or introductions to chapters are printed using a very deep red colour of ink and the texts all start with a large historiated initial. In the Gospel texts, the chapter headings are decorated with large prints and dark colours. These prints are reminiscent of the design of a corona. If we look more closely at the centre of some, we see a pitcher who grows plants.

It is not clear how these old books travelled so far from Polish territory. One can only assume that they were obtained from different sources. Some are probably a part of a family legacy transported by now forgotten people. These people certainly were pious and religious and gave their books to the church. Long centuries of persecution and the threat of retaliation induced 
a culture of distrust toward people of different faiths. For those reasons we do not have any evidence of how these precious books found their way to a church in Tarbagatai.

But the thing we can be sure of is that they are now very precious monuments of literature, according to their age and the places they were printed. They constitute a still unknown documentation of the roots of the culture of ancient Poland. The need for research concerning the Russian Greek Catholic Church is growing. A thorough study of the literature of the Russian minority in the lands of former eastern Poland seems to be an expedient step. For the purpose of these historical and literary studies, it is also necessary to organize an expedition to Siberia, armed with a good knowledge of the ancient Slavic religious language still used nowadays in some churches of eastern Poland.

\section{Acknowledgments}

I would like to thank the priest Sergiej Palij giving me access to the books. I would like to thank Sergiej Popkow - bishop of the Orthodox Church of the Old Believers for helping me translate the Old-Slavonic language.

\section{References}

Cubrzyńska-Leonarczyk M. (2007). Dziedzictwo Unii Brzeskiej. Z dziejów oficyny wydawniczej OO Bazylianów w Supraślu (1695 - 1803). Warszawa - Białystok.

Górski K. (1996). Wstęp, in: Rozmyślania dominikańskie, wyd. i oprac. K. Górski, W. Kuraszkiewicz, Z. Rozanow (oprac. ikonograficzne), T. Dobrzeniecki (wstęp komparatystyczny). Warszawa: XLI-XLII.

Iwaniec E. (1977). Z dziejów staroobrzędowców na ziemiach polskich. Warszawa.

Korolko M. (eds.) (1978). Pieśni postne starożytne. Warszawa.

Michałowska T. (1996). Średniowiecze. Warszawa.

Nieznanowski S. (1989). Średniowieczna liryka religijna. Rekonesans badawczy, in: Tenże, Studia $i$ wizerunki. O poezji staropolskiej i jej badaczach. Warszawa.

Prejs M. (1989). Poezja późnego baroku. Główne kierunki przemian. Warszawa.

Przybył E. (1999). W cieniu Antychrysta. Idee staroobrzędowców w XVII w. Kraków.

Rzepka W., Wydra W. (1996). Cały świat nie pomieściłby ksiag. Staropolskie opowieści i przekazy apokryficzne. Warszawa-Poznań. 